\title{
Factors Affecting College Students' Entrepreneurial Intentions
}

\author{
Haiyan Zhao \\ School of Business Administration \\ Qilu University of Technology \\ Jinan, China
}

\author{
Ruiyu Wang \\ School of Business Administration \\ Qilu University of Technology \\ Jinan, China
}

\begin{abstract}
The employment of college graduates are facing severe challenges. To solve this problem we must actively promote their own businesses and flexible employment, and update the employment ideas and models, thus help them create employment opportunities for themselves. In order to analyze the key factors affecting students' entrepreneurial intentions; we aim to build a new model of affecting students' entrepreneurial intentions from the perspectives of personality traits, entrepreneurial ability, and entrepreneurial environment. In a sample of the university students in Jinan, using research literature analysis, questionnaire and SPSS21, we conduct an analysis into the data and make the specific recommendations based on the results.
\end{abstract}

Keywords-Personality traits, Entrepreneurial ability, Entrepreneurial environment, Factors, College students

\section{INTRODUCTION}

With the further development of higher education reform, the continuous expansion of college enrollment makes the number of college graduates rise sharply, therefore college graduates are under the huge employment pressure. In the meantime, China's economic growth is in transition, in face of tremendous transition pressure. As the most dynamic part of economic development, Entrepreneurship can create a large number of jobs, thus is one of the effective ways to solve the employment problem and to promote sustained economic growth. In the press of entrepreneurship and innovation, the college students are the most concerned groups. Therefore, they are involved in a number of common topics of concern, such as developing their entrepreneurial quality and awareness, encouraging college students start their own businesses, and helping college students dream put down roots.

Entrepreneurship is a complex social activity involving multiple disciplines. The relevant research abroad started earlier than the domestic one and has achieved fruitful research results. However, the overseas studies are based on foreign research specific environment, thus the research results are not necessarily suited to China's special economic systems. Therefore, based on China's national conditions and the existing studies, this study adopts the variables of personality traits, entrepreneurial abilities and environment to investigate their impact on entrepreneurial intention.

\section{RESEARCH DESIGN}

Since the junior college students i.e. freshmen and sophomores, have just entered the university, they have simple thoughts, and lack of social experience, thus have no pressure on employment. Therefore, the sample of this study is based on senior college students in ten colleges in Jinan.

The survey adopts sound questionnaire design, and 350 questionnaires were distributed. After excluding non-standard and invalid.

\section{DATA ANALYSIS}

\section{A. Data Statistics}

TABLE I. DATA STATISTICS

\begin{tabular}{cccc}
\hline $\begin{array}{l}\text { Respondents In- } \\
\text { formation }\end{array}$ & Type & Number & $\begin{array}{c}\text { Percent- } \\
\text { age\% }\end{array}$ \\
\hline Gender & male & 112 & 35 \\
& female & 208 & 65 \\
Age & $18-22$ & 141 & 44.1 \\
& $23-25$ & 179 & 55.9 \\
Grade & third & 162 & 50.6 \\
& forth & 158 & 49.4 \\
Hometown & urban & 79 & 24.7 \\
Educational back- & rural & 241 & 75.3 \\
ground & college & 28 & 8.8 \\
Major & undergraduate & 292 & 91.2 \\
& Arts and science & 185 & 58 \\
\hline
\end{tabular}

As showed in Table 1, boys in the survey account for $5 \%$, and girls account for $65 \%$; the range in age is from 18 to 25 years, of which $18-22$ years old account for $44.1 \%, 23-25$ years old account for $55.9 \% ; 75.3 \%$ of the respondents are from rural areas, and $24.7 \%$ are from urban cities; undergraduate education accounts for $91.2 \%$, college education accounts for $8.8 \%$; arts and science students account for $58 \%$, the proportion of social science is $42 \%$. 
B. Correlation Analysis

TABLE II. CORRELATION MATRIX

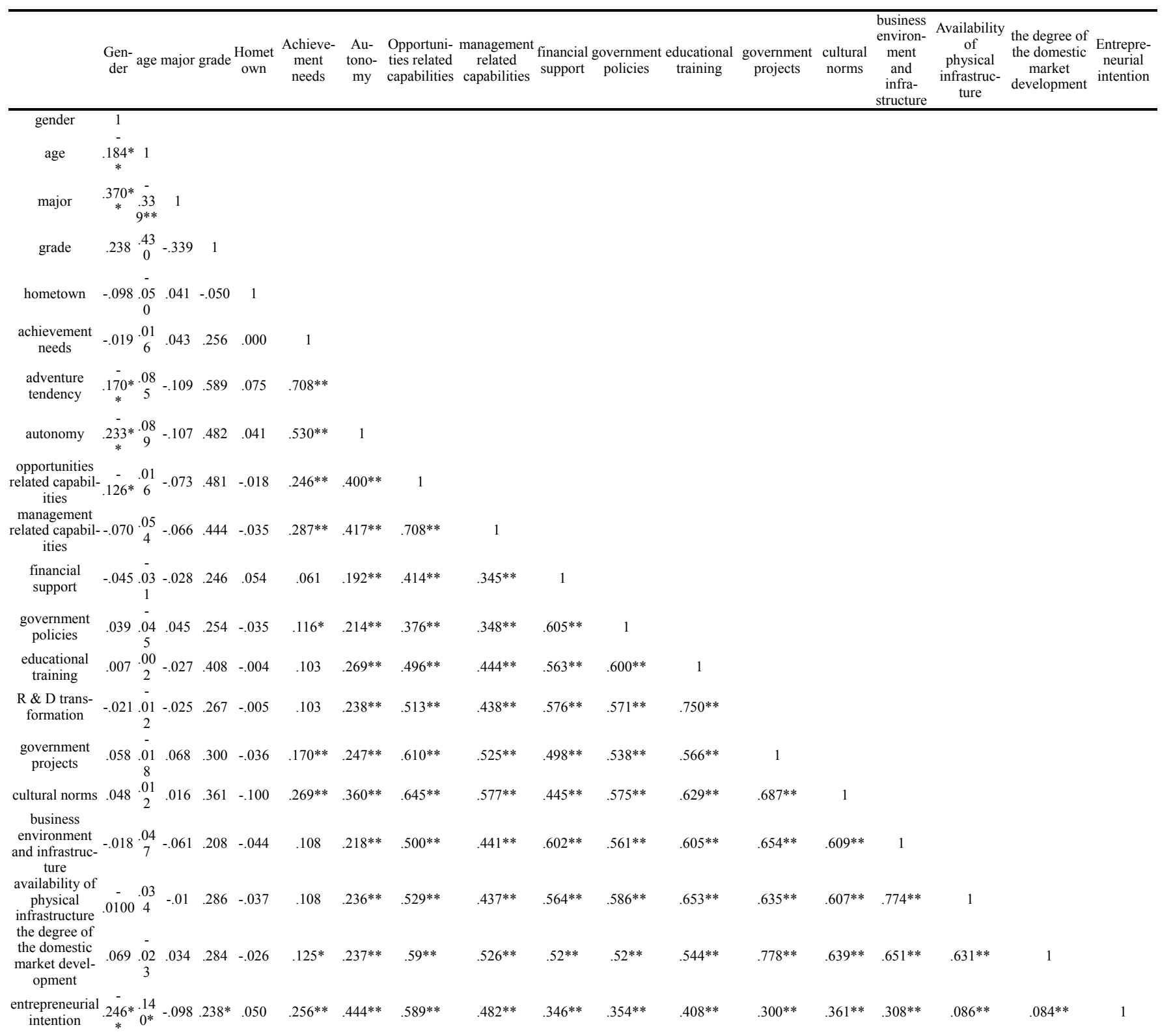

Table2 shows the following:

1) Individual background

In terms of individual background, gender and major are positively correlated( $r=.370$, Sig. $<0.01)$, which means that males and females have differences in choosing major; age and entrepreneurial intention are positively correlated $=.140$, Sig. $<0.05$ ), meaning that the students' entrepreneurial intentions have been growing with age, and the more clear their business objectives are, the stronger entrepreneurial perseverance is; grade and entrepreneurial intention are also positively correlated $(r=.238$, Sig. $<0.05)$. However, gender and entrepreneurial intention was negatively correlated(r=-.246, Sig. $<0.01$ ), meaning that there are differences in entrepreneurial intention between boys and girls. And boys are stronger than girls in terms of entrepreneurial intention, which is consistent with previous findings.

2) Relationship between Personality Traits and Entrepreneurial Intention

In the three dimensions of personality traits, achievement needs and adventure tendency $(\mathrm{r}=.708$, Sig. $<0.01)$, autonomy $(\mathrm{r}=.530$,Sig. $<0.01)$ are positively correlated, which means that the students willing to pursue personal achievements are also adventurous students who actively seek opportunities for success; achievement needs $(\mathrm{r}=.256$, Sig. $<0.01)$, adventure tendency $(\mathrm{r}=.481$,Sig. $<0.01)$, autonomy $(\mathrm{r}=.444$,Sig. $<0.01)$ are positively correlated with entrepreneurial intention, where adventure tendency and autonomy have a higher correlation coefficient with a Sig. value less than 0.01 , and achievement need 
and entrepreneurial intention have a lower correlation coefficient with a Sig. value of greater than 0.05 . This means that achievement need, adventure tendency and autonomy are positively affect entrepreneurial intention. Therefore, the three dimensions of personality traits have an impact on entrepreneurial intention.

3) Relationship between Personality Traits and Entrepreneurial Capacities

Opportunities related capabilities and the three dimensions of personality traits i.e. achievement needs $(r=.246$, Sig. $<0.01)$, adventure tendency $(\mathrm{r}=.397$, Sig. $<0.01)$ and autonomy $(\mathrm{r}=.400$, Sig. $<0.01$ ), are positively correlated; management related capabilities and the three dimensions of personality traits i.e. achievement needs $(r=.402$, Sig. $<0.01)$, adventure tenden$\operatorname{cy}(\mathrm{r}=.417$, Sig. $<0.01)$, and autonomy $(\mathrm{r}=.708$, Sig. $<0.01)$ are all positively correlated. In particular, opportunities related capabilities are significantly associated with adventure tendency and autonomy, are less associated with achievement needs; management related capabilities are significantly associated with adventure tendency and achievement needs, are highly associated with autonomy. Therefore, the three dimensions of personality traits have an impact on the two dimensions of entrepreneurial ability, and personality traits and entrepreneurial ability are positively correlated.

4) Relationship between Entrepreneurial Environment and Entrepreneurial Intentions

There are nine dimensions of business environment i.e. entrepreneurial intentions and financial support $(\mathrm{r}=.346$, Sig. $<0.01)$, government policies $(\mathrm{r}=.354$, Sig. $<0.01)$, educational training(r=.408, Sig. $<0.01), \mathrm{R} \& \mathrm{D}$ transformation $(\mathrm{r}=.267$, Sig. $<0.01)$, government projects $(r=.300, \quad$ Sig. $<0.01)$, cultural norms $(\mathrm{r}=.361$, Sig. $<0.01)$, business environment and infrastructure $(\mathrm{r}=.308$, Sig. $<0.01)$, availability of physical infrastructure $(r=.086$, Sig. $<0.01)$, and the degree of domestic market development( $\mathrm{r}=.084$, Sig. $<0.01)$, where entrepreneurial intention has a correlation coefficient of greater than 0.3 with financial support, government policies, educational training, cultural norms, business environment and infrastructure, which is significant; has a correlation coefficient in a range between 0.2 and 0.3 with $\mathrm{R} \& \mathrm{D}$ transformation and government projects, that is, they are correlated to some extent; and has a lower correlation coefficient of less than 0.1 with availability of physical infrastructure and the degree of domestic market development. To sum up, the various dimensions of the business environment have an impact on entrepreneurial intention, but to varying degrees.

5) Relationship between Entrepreneurial Environment and Entrepreneurial Ability.

Opportunities related capabilities and financial support $(\mathrm{r}=.414$, Sig. $<0.01)$, government policies $(\mathrm{r}=.376$, Sig. $<0.01)$, educational training $(\mathrm{r}=.496, \mathrm{Sig} .<0.01), \mathrm{R} \& \mathrm{D}$ transformation $(\mathrm{r}=.513$, Sig. $<0.01)$, government projects $(\mathrm{r}=.610$, Sig. $<0.01)$, cultural norms, $(\mathrm{r}=.645$, Sig. $<0.01)$, business environment and infrastructure $(\mathrm{r}=.500$, Sig. $<0.01)$, availability of physical infrastructure $(r=.529$, Sig. $<0.01)$, the degree of the domestic market development $(\mathrm{r}=.590, \mathrm{Sig} .<0.01)$ are all positively correlated; management related capacities and financial support $(\mathrm{r}=.345$, Sig. $<0.01)$, government policies $(\mathrm{r}=.348$, Sig. $<0.01)$, educational training $(\mathrm{r}=.444$, Sig. $<0.01), \mathrm{R} \& \mathrm{D}$ transformation $(\mathrm{r}=.438$, Sig. $<0.01)$, government projects $(\mathrm{r}=.525$, Sig. $<0.01)$, cultural norms $(\mathrm{r}=.577$, Sig. $<0.01)$, business environment and infrastructure $(\mathrm{r}=.441$, Sig. $<0.01)$, availability of physical infrastructure $(\mathrm{r}=.437$, Sig. $<0.01)$, and the degree of the domestic market development $(\mathrm{r}=.526$, Sig. $<0.01)$ are also positively correlated。

6) Relationship between Entrepreneurial ability and Entrepreneurial Intention

In the two dimensions of entrepreneurial ability, opportunities related capabilities have a significant and higher correlation coefficient with entrepreneurial intentions $(r=0.589$, Sig. $<0.01)$, which means that opportunities related capabilities and entrepreneurial intention are positively correlated; management related capacities have a significant and higher correlation coefficient with entrepreneurial intentions (0.482, Sig. $<0.01)$, meaning that management related capacities and entrepreneurial intention are positively correlated. Consequently, the students' entrepreneurial ability and entrepreneurial intention have a significant positive correlation.

\section{Regression Analysis}

1) The Effects of Personality Traits on Entrepreneurial Intentions

TABLE III. REGRESSION ANALYSIS OF THE EFFECTS OF PERSONALITY TRAITS ON ENTREPRENEURIAL INTENTIONS

\begin{tabular}{|c|c|c|c|c|c|}
\hline & & \multicolumn{2}{|c|}{ model1a } & \multicolumn{2}{|c|}{ model1b } \\
\hline & & $\beta$ & Sig & $\beta$ & Sig \\
\hline \multirow{10}{*}{ 总 } & gender & -0.529 & 0.000 & -0.234 & 0.034 \\
\hline & age & 0.173 & 0.091 & 0.086 & 0.325 \\
\hline & major & 0.118 & 0.402 & 0.058 & 0.619 \\
\hline & hometown & 0.007 & 0.858 & 0.186 & 0.107 \\
\hline & $\begin{array}{l}\text { Achievement } \\
\text { needs }\end{array}$ & & & 0.113 & 0.005 \\
\hline & autonomy & & & 0.276 & 0.004 \\
\hline & $\begin{array}{l}\text { adventure } \\
\text { tendency }\end{array}$ & & & 0.675 & 0.000 \\
\hline & $\mathrm{R} 2$ & & & & \\
\hline & Max-VIF & & & & \\
\hline & F-test & -0.529 & 0.000 & 29.082 & 0.000 \\
\hline
\end{tabular}

As showed in Table3, all the dimension coefficients of the sistent with the expectations. Model $1 \mathrm{~b}$ has an adjusted R2 of 0.381 , which is more than the R2 value of model $1 \mathrm{a}, 0.061$. variables of personality traits in Model $1 \mathrm{~b}$ are positive, con- 
models can explain the increasing proportion of the total variations, and the introduction of the three dimensions of personality traits is effective, where, achievement needs, autonomy, and adventure tendency have a significant effect on college students' entrepreneurial intentions.

2) The Effects of Entrepreneurial Capacities on Entrepreneurial Intentions

TABLE IV. REGRESSION ANALYSIS OF THE EFFECTS OF ENTREPRENEURIAL CAPACITIES ON ENTREPRENEURIAL INTENTIONS

\begin{tabular}{|c|c|c|c|c|c|}
\hline \multicolumn{6}{|c|}{ Regression analysis of the effects of entrepreneurial capacities on Entrepreneurial Intentions } \\
\hline & & \multicolumn{2}{|c|}{ model2a } & \multicolumn{2}{|c|}{ model $2 b$} \\
\hline & & $\boldsymbol{\beta}$ & Sig & $\beta$ & Sig \\
\hline \multirow{9}{*}{$\begin{array}{l}\text { entre- } \\
\text { pre- } \\
\text { neurial } \\
\text { capaci- } \\
\text { ties }\end{array}$} & gender & -0.529 & 0.000 & -0.389 & 0.001 \\
\hline & age & 0.173 & 0.091 & 0.148 & 0.114 \\
\hline & major & 0.118 & 0.402 & 0.014 & 0.911 \\
\hline & hometown & 0.007 & 0.858 & 0.198 & 0.108 \\
\hline & $\begin{array}{c}\text { opportunities related } \\
\text { capabilities }\end{array}$ & & & 0.317 & 0.000 \\
\hline & $\begin{array}{l}\text { management related } \\
\text { capacities }\end{array}$ & & & 0.236 & 0.002 \\
\hline & $\mathrm{R} 2$ & & & & \\
\hline & Max-VIF & & & & \\
\hline & F-test & 6.161 & 0.000 & 22.697 & 0.000 \\
\hline
\end{tabular}

As showed in Table 4, all the dimension coefficients of entrepreneurial ability in model $2 \mathrm{~b}$ are positive, which is consistent with the expectations. Model $2 \mathrm{~b}$ has an adjusted R2 of 0.290 , which is more than the R2 value of model $2 \mathrm{a}, 0.061$. This means, after the introduction of entrepreneurial ability, the models can explain the increasing proportion of the total variations, and the introduction of the two dimensions of entrepre- neurial ability is effective. Of which, entrepreneurial ability have a positive effect on entrepreneurial intentions, as well, opportunities related capabilities and management related capacities have a positive effect on entrepreneurial intentions.

3) The Effects of Entrepreneurial Environment on Entrepreneurial Intentions

TABLE V. REGRESSION ANALYSIS OF THE EFFECTS OF ENTREPRENEURIAL ENVIRONMENT ON ENTREPRENEURIAL INTENTIONS

\begin{tabular}{|c|c|c|c|c|c|}
\hline & \multicolumn{4}{|c|}{ The effects of entrepreneurial environment on entrepreneurial intentions } & model3b \\
\hline & & $\beta$ & Sig & $\beta$ & Sig \\
\hline \multirow{16}{*}{ 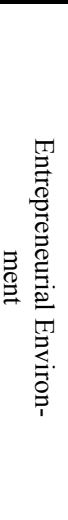 } & gender & -0.529 & 0.000 & -0.578 & 0.086 \\
\hline & age & 0.173 & 0.091 & 0.163 & 0.000 \\
\hline & major & 0.118 & 0.402 & 0.030 & 0.090 \\
\hline & hometown & 0.007 & 0.858 & 0.104 & 0.816 \\
\hline & financial support & & & 0.034 & 0.014 \\
\hline & government policies & & & 0.018 & 0.049 \\
\hline & Educational training & & & 0.389 & 0.000 \\
\hline & $\mathrm{R} \& \mathrm{D}$ transformation & & & 0.131 & 0.083 \\
\hline & business environment & & & 0.201 & 0.107 \\
\hline & infrastructure & & & 0.048 & 0.118 \\
\hline & cultural and social norms & & & 0.233 & 0.007 \\
\hline & government projects & & & 0.081 & 0.061 \\
\hline & market opening up & & & 0.096 & 0.344 \\
\hline & $\mathrm{R} 2$ & & & & \\
\hline & Max-VIF & & & & \\
\hline & F-test & 6.161 & 0.000 & 9.737 & 0.000 \\
\hline
\end{tabular}

As showed in Table5, all the dimension coefficients of the variables in Model $3 \mathrm{~b}$ are positive, consistent with the expectations. Model $3 \mathrm{~b}$ has an adjusted R2 of 0.263 , which is more than the R2 value of model 3a, 0.061. This means, after the introduction of the personality traits, the models can explain the increasing proportion of the total variations, and the introduction of the nine dimensions of personality traits is effective. Of which, government policies, financial support, cultural norms, and educational training have a significant effect on college students' entrepreneurial intentions $(\mathrm{Sig}<0.05)$; to some extent, R \& D transformation and government projects have an effect on college students' entrepreneurial intentions ( $\operatorname{Sig}<0.10)$; business environment, physical infrastructure and market opening up have no effect on college students' entrepreneurial intentions $(\operatorname{Sig}>0.10)$. 


\section{4) The mediating Effects of Entrepreneurial ability}

TABLE VI. THE MEDIATING EFFECTS OF OPPORTUNITIES RELATED CAPABILITIES BETWEEN PERSONALITY TRAITS AND ENTREPRENEURIAL INTENTIONS

\begin{tabular}{|c|c|c|c|c|c|c|}
\hline \multicolumn{7}{|c|}{ The mediating effects of opportunities related capabilities between personality traits and entrepreneurial intention } \\
\hline \multirow{2}{*}{$\begin{array}{c}\begin{array}{c}\text { dependent varia- } \\
\text { bles }\end{array} \\
\begin{array}{c}\text { Independent varia- } \\
\text { bles }\end{array}\end{array}$} & \multicolumn{2}{|c|}{ Model a1 } & \multicolumn{2}{|c|}{ Model a2 } & \multicolumn{2}{|c|}{ Model a3 } \\
\hline & \multicolumn{2}{|c|}{ entrepreneurial intentions } & \multicolumn{2}{|c|}{$\begin{array}{c}\text { opportunities related capabili- } \\
\text { ties }\end{array}$} & \multicolumn{2}{|c|}{ entrepreneurial intentions } \\
\hline achievement needs & 0.113 & 0.005 & 0.021 & 0.845 & 0.119 & 0.198 \\
\hline autonomy & 0.276 & 0.004 & 0.358 & 0.001 & 0.176 & 0.061 \\
\hline adventure tendency & 0.675 & 0.000 & 0.329 & 0.000 & 0.583 & 0.002 \\
\hline \multicolumn{7}{|l|}{$\begin{array}{l}\text { Mediating varia- } \\
\text { bles }\end{array}$} \\
\hline $\begin{array}{l}\text { opportunities relat- } \\
\text { ed capabilities }\end{array}$ & & & & & 0.280 & 0.000 \\
\hline $\mathrm{R} 2$ & \multicolumn{2}{|c|}{0.381} & \multicolumn{2}{|c|}{0.182} & \multicolumn{2}{|c|}{0.437} \\
\hline Max-VIF & \multicolumn{2}{|c|}{2.001} & \multicolumn{2}{|c|}{1.984} & \multicolumn{2}{|c|}{2.054} \\
\hline F-test & 29.082 & 0.000 & 11.124 & 0.000 & 31.903 & 0.000 \\
\hline
\end{tabular}

As showed in Model a1 of Table6, all the dimension coefficients of the variables in Model $3 \mathrm{~b}$ are positive, consistent with the expectations. Model $3 \mathrm{~b}$ has an adjusted R2 of 0.263 , which is more than the R2 value of model 3a, 0.061. achievement needs $(\beta=0.113, \operatorname{Sig}<=0.05)$, adventure tendency $(\beta=0.675$, Sig $<0.001)$, and autonomy $(\beta=0.276$, Sig $<0.01)$ are all positively correlated with entrepreneurial intentions. In model a2, adventure tendency $(\beta=0.329$, Sig $<0.001$ ) and autonomy ( $\beta$ $=0.358$, Sig $<0.01$ ) are positively correlated with opportunities related capabilities, but achievement needs $(\beta=0.021$, Sig $>0.05)$ is insignificantly correlated with opportunities related capabilities, thus the regression ends up. As showed in model a3, adventure tendency $(\beta=0.583$, Sig $<0.001$ ) and opportunities related capabilities $(\beta=0.028$, Sig $<0.001)$ have a significant effect on entrepreneurial intentions, but autonomy ( $\beta=0.176$,
Sig $>0.05)$ has no significant effect on entrepreneurial intentions. Therefore, personality traits have a significant effect on entrepreneurial intentions by way of entrepreneurial ability, whereas achievement needs has no significant effect on opportunities related capabilities thus there is no mediating effect. Autonomy has an effect on entrepreneurial intentions and opportunities related capabilities respectively. When the independent variables and the mediating variables are added to the models, the significance of autonomy is dropping, that is, there is a complete mediating effect. In a similar vein, adventure tendency has an effect on entrepreneurial intentions and opportunities related capabilities respectively. When the independent variables and the mediating variables are added to the models, the correlation is dropping, that is, there is an in part mediating effect.

TABLE VII. THE MEDIATING EFFECTS OF MANAGEMENT RELATED CAPABILITIES BETWEEN PERSONALITY TRAITS AND ENTREPRENEURIAL INTENTIONS

\begin{tabular}{|c|c|c|c|c|c|c|}
\hline \multicolumn{7}{|c|}{ The mediating effects of management related capabilities between personality traits and entrepreneurial intentions } \\
\hline \multirow[b]{2}{*}{$\begin{array}{c}\text { dependent varia- } \\
\text { bles }\end{array}$} & \multicolumn{2}{|c|}{ Model b1 } & \multicolumn{2}{|c|}{ Model b2 } & \multicolumn{2}{|c|}{ Model b3 } \\
\hline & $\begin{array}{c}\boldsymbol{\beta} \\
\text { entreprer }\end{array}$ & $\begin{array}{c}\text { Sig } \\
\text { tentions }\end{array}$ & $\underset{\text { managemer }}{\beta}$ & $\underset{\text { deapabili- }}{\text { Sig }}$ & $\begin{array}{c}\boldsymbol{\beta} \\
\text { entrepren }\end{array}$ & $\begin{array}{c}\text { Sig } \\
\text { tentions }\end{array}$ \\
\hline \multicolumn{7}{|l|}{$\begin{array}{l}\text { Independent varia- } \\
\text { bles }\end{array}$} \\
\hline achievement needs & 0.113 & 0.005 & 0.085 & 0.006 & 0.134 & 0.151 \\
\hline autonomy & 0.276 & 0.004 & 0.356 & 0.000 & 0.184 & 0.053 \\
\hline adventure tendency & 0.675 & 0.000 & 0.284 & 0.001 & 0.602 & 0.060 \\
\hline \multicolumn{7}{|l|}{$\begin{array}{l}\text { Mediating varia- } \\
\text { bles }\end{array}$} \\
\hline $\mathrm{R} 2$ & \multicolumn{2}{|c|}{0.381} & \multicolumn{2}{|c|}{0.195} & \multicolumn{2}{|c|}{0.419} \\
\hline Max-VIF & \multicolumn{2}{|c|}{2.001} & \multicolumn{2}{|c|}{1.984} & \multicolumn{2}{|c|}{2.066} \\
\hline F-test & 29.082 & .000 & 12.022 & 0.000 & 29.771 & 0.000 \\
\hline
\end{tabular}


As showed in Model b1 of Table7, achievement needs( $\beta$ $=0.113, \operatorname{Sig}<=0.05)$, adventure tendency $(\beta=0.675$, Sig $<0.001)$, and autonomy $(\beta=0.276, \operatorname{Sig}<0.01)$ are all positively correlated with entrepreneurial intentions. In model b2, adventure ten$\operatorname{dency}(\beta=0.329$, Sig $<0.001$, autonomy $(\beta=0.358$, Sig $<0.01$ ), and achievement needs( $\beta=0.085$, Sig $<0.01$ )are positively correlated with management related capabilities. As showed in model b3, when achievement needs, adventure tendency, autonomy. and management related capabilities act as Independent variables, and entrepreneurial intentions act as dependent variables, achievement needs ( $\beta=0.134$, Sig $>0.05$ ), and autonomy ( $\beta=0.184$, Sig $>0.05$ )are no longer significantly correlated with entrepreneurial intentions, but adventure tendency $\beta$ $=0.583, \mathrm{Sig}<0.01)$ and management related capabilities $(\beta$ $=0.028$, Sig $<0.001$ )are significantly correlated with entrepreneurial intentions. Therefore, management-related capabilities has a fully mediating effect between achievement needs, autonomy and entrepreneurial intention, but has a partially mediating effect between adventure tendency and entrepreneurial intentions.

TABLE VIII. THE MEDIATING EFFECTS OF OPPORTUNITIES RELATED CAPABILITIES BETWEEN ENTREPRENEURIAL ENVIRONMENT AND ENTREPRENEURIAL INTENTIONS

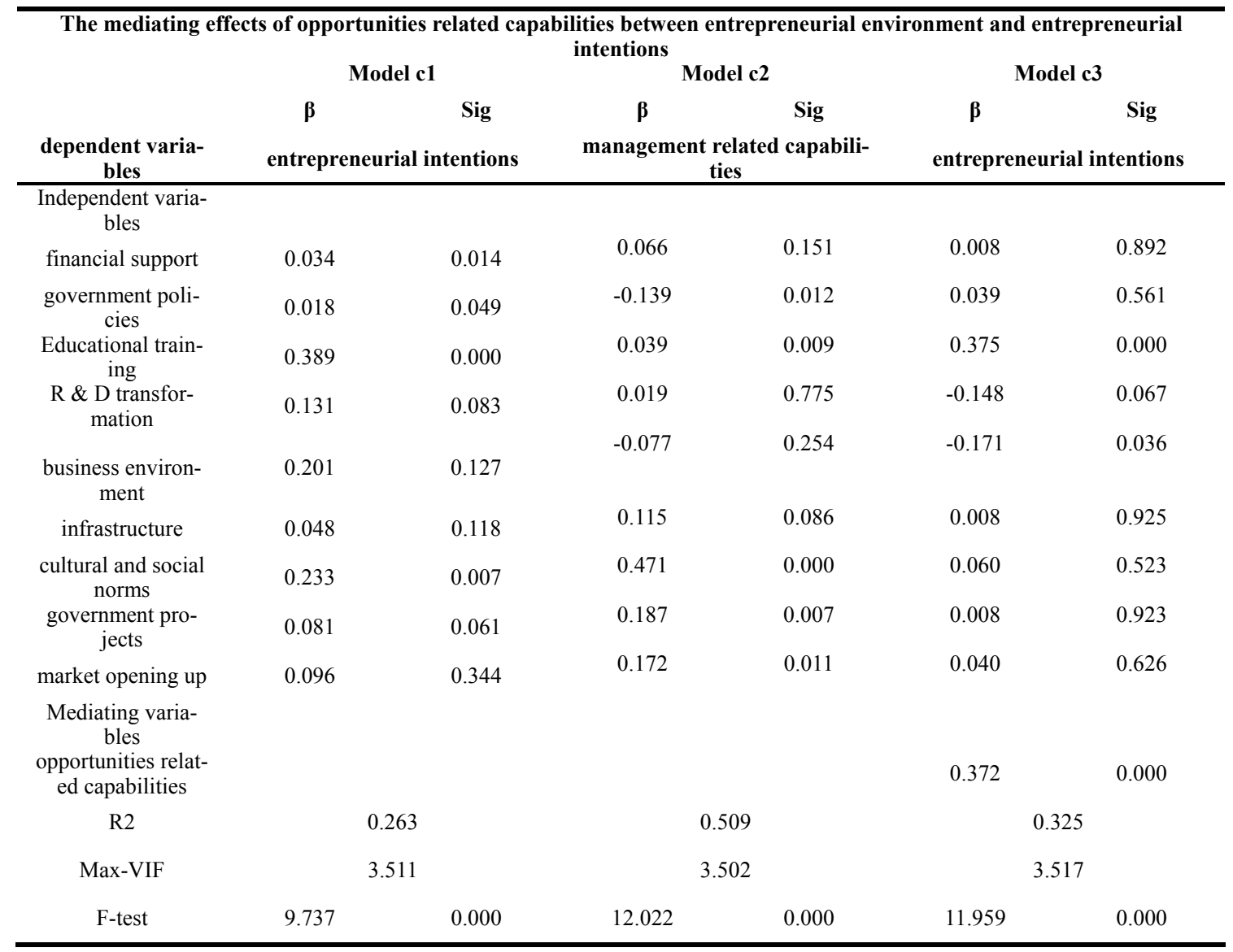

As showed in Model $\mathrm{c} 1$ of Table8, educational training ( $\beta$ $=0.389$, Sig $<0.01$ ), cultural norms $(\beta=0.233$, Sig $<0.01)$, government policies $(\beta=0.018$, Sig $<0.05$ ), financial support ( $\beta$ $=0.034$, Sig $<0.05$ ) have a significant effect on entrepreneurial intentions. In Model $c 2$, educational training ( $\beta=0.039$, $\operatorname{Sig}<0.01)$, cultural norms $(\beta=0.471$, Sig $<0.001$ ), and government policies $(\beta=-0.139, \operatorname{Sig}<0.05)$ have a significant effect on opportunities related capabilities, but financial support have no significant effect on opportunities related capabilities. In Model c3, educational training $(\beta=0.375$, Sig $<0.001)$ and opportunities related capabilities $(\beta=-0.372$, $\operatorname{Sig}<0.001)$ have a significant effect on entrepreneurial intentions. However, cultural $\operatorname{norms}(\beta=0.060, \operatorname{Sig}>0.05)$ and government policies $(\beta=-0.039$, Sig $>0.05$ have no longer significant effects on entrepreneurial intentions. This means, opportunities related capabilities has mediating effects between cultural norms, government policies and entrepreneurial intentions, has a partially mediating effect between educational training and entrepreneurial intentions, and has no mediating effect between the other variables. 
TABLE IX. TESTS ON THE MEDIATING EFFECTS OF MANAGEMENT RELATED CAPABILITIES BETWEEN ENTREPRENEURIAL ENVIRONMENT AND ENTREPRENEURIAL INTENTIONS

\begin{tabular}{|c|c|c|c|c|c|c|}
\hline \multicolumn{7}{|c|}{$\begin{array}{c}\text { Tests on the mediating effects of management related capabilities between entrepreneurial environment and entrepre- } \\
\text { neurial intentions }\end{array}$} \\
\hline \multirow[b]{3}{*}{$\begin{array}{l}\text { dependent varia- } \\
\text { bles }\end{array}$} & \multicolumn{2}{|c|}{ Model d1 } & \multicolumn{2}{|c|}{ Model d2 } & \multicolumn{2}{|c|}{ Model d3 } \\
\hline & $\beta$ & Sig & $\beta$ & Sig & $\beta$ & Sig \\
\hline & \multicolumn{2}{|c|}{ entrepreneurial intentions } & \multicolumn{2}{|c|}{$\begin{array}{l}\text { management related capabili- } \\
\text { ties }\end{array}$} & \multicolumn{2}{|c|}{ entrepreneurial intentions } \\
\hline \multicolumn{7}{|l|}{$\begin{array}{l}\text { Independent varia- } \\
\text { bles }\end{array}$} \\
\hline financial support & 0.034 & 0.014 & 0.025 & 0.604 & 0.024 & 0.666 \\
\hline $\begin{array}{l}\text { government poli- } \\
\text { cies }\end{array}$ & 0.018 & 0.049 & -0.066 & 0.250 & 0.008 & 0.902 \\
\hline $\begin{array}{l}\text { Educational train- } \\
\text { ing }\end{array}$ & 0.389 & 0.000 & 0.080 & 0.005 & 0.363 & 0.000 \\
\hline $\begin{array}{l}\mathrm{R} \& \mathrm{D} \text { transfor- } \\
\text { mation }\end{array}$ & 0.131 & 0.083 & -0.024 & 0.729 & -0.133 & 0.102 \\
\hline $\begin{array}{l}\text { business environ- } \\
\text { ment }\end{array}$ & 0.201 & 0.127 & -0.010 & 0.889 & -0.197 & 0.017 \\
\hline infrastructure & 0.048 & 0.118 & 0.005 & 0.937 & 0.048 & 0.549 \\
\hline $\begin{array}{l}\text { cultural and social } \\
\text { norms }\end{array}$ & 0.233 & 0.007 & 0.395 & 0.000 & 0.108 & 0.241 \\
\hline $\begin{array}{l}\text { government pro- } \\
\text { jects }\end{array}$ & 0.081 & 0.061 & 0.111 & 0.123 & 0.042 & 0.613 \\
\hline market opening up & 0.096 & 0.344 & 0.187 & 0.008 & 0.044 & 0.595 \\
\hline $\begin{array}{l}\text { Mediating varia- } \\
\text { bles } \\
\text { management relat- } \\
\text { ed capabilities }\end{array}$ & & & & & 0.321 & 0.000 \\
\hline $\mathrm{R} 2$ & & & & & & \\
\hline Max-VIF & & & & & & \\
\hline F-test & 9.737 & 0.000 & 15.645 & 0.000 & 15.645 & 0.000 \\
\hline
\end{tabular}

As showed in Model d1 of Table 9, educational training ( $\beta$ $=0.389$, Sig $<0.01)$, cultural norms $(\beta=0.233$, Sig $<0.01)$, government policies( $\beta=0.018$, Sig $<0.05)$, financial support $(\beta$ $=0.034$, Sig $<0.05$ )have a significant effect on entrepreneurial intentions. In Model $\mathrm{d} 2$, educational training $(\beta=0.080$, $\operatorname{Sig}<0.01)$, cultural norms $(\beta=0.395$, Sig $<0.001$ )have a significant effect on management related capabilities, but financial support ( $\beta=0.066$, Sig. $>0.05$ ) and government policies ( $\beta$ $=0.066$, Sig. $>0.05$ ) have no significant effect on management related capabilities. In Model c3, educational training ( $\beta$ $=0.375, \operatorname{Sig}<0.001)$ and opportunities related capabilities $(\beta$ $=0.372$, Sig $<0.001$ )have a significant effect on entrepreneurial intentions. However, cultural norms $(\beta=0.060$, Sig $>0.05)$ has no longer significant effects on entrepreneurial intentions. This means, opportunities related capabilities has fully mediating effects between cultural norms and entrepreneurial intentions, has a partially mediating effect between educational training and entrepreneurial intentions, and has no mediating effect between the other variables.

\section{CONCLUSION AND SUGGESTIONS}

This study on the relationships between personality traits, entrepreneurial ability, entrepreneurial environment and entrepreneurial intentions can conclude in the following aspects:

Personality traits: the people who have high need for achievement than those who demand low achievement are often easier to select high risk, highly challenging work. In order to achieve the intended objectives, they are willing to actively seek solutions to the problems, and constantly change work methods. Therefore, the colleges should change the traditional concept of employment, and actively promote the national call for their own businesses, and conduct entrepreneurial courses, and foster the awareness of self-employment and entrepreneurial ability, thus enrich college students' business knowledge and entrepreneurial skills. Meanwhile, the colleges should attach importance to cultivate the spirit of active learning, to foster collaboration and sense of team unity and spirit of innovation, to train students' desire for success, and to actively encourage students to challenge themselves.

Entrepreneurial ability: For college students, the colleges should improve entrepreneurial ability course structure and content systems, and actively carry out entrepreneurial practice, regularly invites entrepreneur experts to conduct seminars and to train in entrepreneurial skills, improve college students on entrepreneurship awareness. While, the colleges should help college students absorb proven and relatively mature entrepreneurial experience and entrepreneurial theoretical knowledge, thereby increasing the proportion of the contributions of college students' entrepreneurial ability to the future entrepreneur- 
ial activities. We should strengthen education publicity and policy advocacy; build a sound entrepreneurial incentive system. Learning from the mature foreign experience, society, schools and families are encouraged to support students during the school in carrying out various entrepreneurial activities through self-financing and social practice, help them record from the actual business experience in entrepreneurial activities, thus improve college students' entrepreneurial ability and entrepreneurial ability.

Entrepreneurial environment: the relationship between business environment and entrepreneurial intentions imply the following: First, in terms of education, colleges and universities should strengthen the emphasis on entrepreneurship education, perfect entrepreneurship teachers, build a comprehensive entrepreneurial structure and system including entrepreneurial courses, entrepreneurial research, entrepreneurial forums, entrepreneurial competitions, and entrepreneurs' coalition. They should make entrepreneurship education teaching objectives clear and improve entrepreneurship curriculum evaluation system. By means of schools to train, government and business co-funded colleges, and school -business joint training, the colleges and universities should effectively carry out implementation of entrepreneurship practices, enrich the students' practical experience, and thus achieve the school-enterprise win-win situation.

Mainly relying on school support, social institutions investment and government earmarks, financial or non-financial institutions should further increase the open micro-credit for college students. When college students apply for small business loans for business, they should be granted interest-free, free warranty policies and the extended interest-free loans term, Meanwhile, we should set up a special fund for college students' venture as well as actively absorbing social capital. The government should start the process of reduction of transaction costs of various types, including business registration fees, business registration funding, etc. in order to improve the financial support for entrepreneurial activities of college students and to reduce the impact of funding problems on the entrepreneurial outcomes in the entrepreneurial process. At the same time, in terms of venture capital financing, entrepreneurial services, entrepreneurial culture, entrepreneurial education, entrepreneurial policies should be focused on improving and perfecting entrepreneurship-related policies and laws and regulations, improving the legal, technical and other aspects of train- ing and consulting service systems, and creating a good market service environment, legal environment, market competition environment and socio-cultural norms, putting efforts to increase social services and entrepreneurship related activities, increasing market transparency, and improving public attitudes towards entrepreneurial activity. Finally, the government should provide sufficient entrepreneurial projects for college students, as well, carry out the implementation of preferential policies in terms of office space, land for factories, equipment and so on. College students have not yet stepped into the community; lack of economic infrastructure, thus high cost of rent office space, high equipment purchase cost and a variety of manual service fees is an important reason for college students' entrepreneurial discouragement. Therefore, governments at all levels should conscientiously implement the low-rent public housing policy implementation; give qualified students the facilities to apply for public rental housing. Local government organizations should create business zone or business incubator base, increase the support for projects of excellence. A superior entrepreneurial ambience and condition is able to stimulate entrepreneurial intentions of the college students with professional knowledge and new entrepreneurial spirit, thereby increase the possibility of the implementation of entrepreneurial behavior.

\section{REFERENCES}

[1] Yonghong Qian. "Comparative study of personal traits influence on men's and women's entrepreneurial intention [J]". Technical economy, pp.8-13, July 2007.

[2] Zhengxia Peng,Genshu Lu,Hui Kang. "Individual and social environmental factors that affect college students' entrepreneurial intention[J]" .Higher engineering education research, pp.75-82,April 2012.

[3] Dandan Jian,Jinyun Duan, Yuelong Zhu. "Entrepreneurial intention measurement, influence factors and the theoretical model of conception[J]". Psychological science progress, pp. 162-169, January 2010.

[4] Limin Duan, Yueping Du. "Entrepreneurship environment influence on college students' entrepreneurial intention: and the GEM model test again [J]". Technical economy, pp. 64-70, 2012.

[5] Zhi Liu,Xingkui Zhang,Yunong Zou. "The latest progress in the study of college students' entrepreneurial intention in China [J]". Journal of northeast normal university (philosophy and social sciences edition), June 2012. 